Volume 8 No. 2, Juli-Desember 2021

P-ISSN: 2406-808X // E-ISSN: 2550-0686

https://journal.iainlangsa.ac.id/index.php/ikhtibar https://doi.org/10.32505/ikhtibar.v8i2.629

\title{
Inovasi Pembelajaran Berbasis Web dalam Implementasi Kurikulum 2013 di MAN Rejang Lebong
}

\author{
Sundari' ${ }^{1}$, Idi Warsah ${ }^{2}$, Beni Azwar ${ }^{3}$ \\ Pascasarjana IAIN Curup \\ ${ }^{1}$ sundari10maret1996@gmail.com
}

\begin{abstract}
Abstrak
Penelitian ini didasarkan pada Inovasi pembelajaran berbasisi Web dan implemntesi dalam kurikulum 2013 di MAN Rejang Lebong. Perihal kebijakan pemerintah pada pendidikan yang mengaharuskan pelaksanaan pembelajaran di masa pandemi Covid-19 ini guru dan siswa harus melakukan aktifitasnya di rumah, sehingga secara tidak langsung sekolah dalam waktu singkat harus mempersiapkan pembelajaran jarak jauh dengan menggunakan pembelajaran secara Daring. Adapun Rumusan masalah dari penelitian ini: yang pertama, Bagaimana Proses pembelajaran yang dilakukan dimasa pandemi Covid19 di MAN Rejang Lebong, ke-2 Bagaimana Inovasi guru dalam mengimplementasi kurikulum 2013 di MAN Rejang Lebong, ke-3 bagaimana cara membentuk karakter kurikulum 2013 di masa pandemi Covid-19. Untuk menemukan dan mengungkapkan jawaban tersebut maka penelitian ini menggunakan pendekatan case study, Lokasi penelitiannya di MAN Rejang Lebong dengan sumber data yang utama diperoleh dari wawancara, observasi, dan dokumentasi. Dan adapun tehnik analisis data diperoleh dari reduksi data, penyajian data dan verifikasi data dengan melaksanakan triangulasi data. Berdasarkan paparan dari hasil penelitian ditemukan bahwa: Proses pembelajaran yang dilakaukan di masa Pandemi Covid-19, membutuhkan proses yang bermacam-macam proses pembelajaran di MAN RL jika dilihat dari ketersediaan sarana teknologi dan informasi yang tersedia hal ini dapat dilihat dari adanya akses internet, ruang komputer dan letak yang tepat di mana juga tersedia 2 ruangan yang khusus untuk melakukan pembelajaran berbasis Web dengan teknologi dan informasi, selama pembelajara daring juga tersedianya android dari masing-masing siswa dan kuota ,sehingga pencapaian proses pembelajaran inovasi dalam teknologi dan informasi di MAN Rejang Lebong dapat terwujud. 2) Inovasi guru dalam mengimplementasi kurikulum 2013 di man rejang lebong, yaitu inovasi pembelajaran berbasisi web dalam bentuk media pembelajaran, inovasi pembelajaran berbasisi web dalam bentuk metode pembelajaran. 3) cara membentuk karakter kurikulum 2013 di MAN Rejang Lebong sudah dapat dikatakan dapat di bentuk dengan cara yang kreatif dan inovatif dilakukan masing-masing guru dalam mengatasi problem pembentukan karakter siswa, sehingga karakter kurikulum 2013 bisa dikatakan tercapai atau terbentuk dengan penilaian yang guru lakukan.
\end{abstract}

\section{Kata kunci: Inovasi, Pembelajaran, web}

\section{Pendahuluan}

Perihal kebijakan pemerintah pada pendidikan yang mengaharuskan pelaksanaan pembelajaran di masa pandemi Covid-19 ini guru dan siswa harus 
melakukan aktifitasnya di rumah, sehingga secara tidak langsung sekolah dalam waktu singkat harus mempersiapkan pembelajaran jarak jauh dengan menggunakan pembelajaran secara daring. Penelitian ini didukung oleh penelitian Baso yang menjelaskan bahwa kunci sukses dalam proses belajar mengajar terletak pada kemampuan guru yang menyampaikan materi pembelajaran yang diberikan. ${ }^{1}$

Agar tujuan dari Pembelajaran tercapai maka perlu adanya pembelajaran yang efektif dimana dalam pembelajaran tersebut digunakan strategi pembelajaran yang tepat, ditetapkan langkah-langkah kegiatan yang akan dilakukan, termasuk saranaprasarana yang digunakan, media yang digunakan, materi yang diberikan, serta metodologi yang digunakan dalam melaksanakan kegiatan pembelajaran. ${ }^{2}$ Guru yang profesional dalam proses belajar-mengajar mampu menciptakan iklim belajar yang baik dan kondusif. Salah satu caranya adalah dengan adanya inovasi pembelajaran. Inovasi pembelajaran berarti suatu perubahan baru yang ada kaitannya dengan suatu pembelajaran untuk mencapai tujuan tertentu. Tujuan dari penelitian ini adalah untuk memberikan gambaran tentang inovasi pembelajaran berbasis web yang diberkan oleh guru.

Dalam suatu sistem pendidikan komponen guru memegang peran kunci dalam menentukan keberhasilan pembelajaran. Guru atau pendidik yang baik adalah makhluk yang kreatif sehingga pada umumnya para guru yang baik selalu mencari pendekatan atau strategi baru inilah yang menimbulkan terwujudnya berbagai macam inovasi dalam pembelajaran. Wujud, bentuk dan upaya inovasi dapat bermacam-macam. Namun demikian, semua memiliki tujuan umum yang sama, yaitu terwujudnya suatu proses pembelajaran berkualitas sehingga dapat meningkatkan kompetensi, kemampuan, keterampilan dan daya saing peserta didik dalam suatu program pendidikan pada jenjang, jenis maupun jalur pendidikan.

\section{Metode Penelitian}

Penelitian ini dapat dikelompokkan ke dalam jenis penelitian kualitatif dengan menggunakan pendekatan case study karena penelitian ini difokuskan dilingkungan MAN Rejang Lebong. Riset studi kasus mencakup studi tentang suatu kasus dalam kehidupan nyata, dalam konteks atau setting kontemporer. Penelitian studi kasus adalah pendekatan kualitatif yang penelitinya mengekplorasi kehidupan nyata, sistem terbatas kontemporer (kasus) atau beragam sisitem terbatas (berbagai kasus) melalui pengumpulan data yang lengkap dan mendalam yang melibatkan beragam sumber informasi (observasi, wawancara, dokumentasi) dan melaporkan deskripsi kasus dan tema kasus. ${ }^{3}$ Posisi Penelitian adalah posisi dimana peneliti memperoleh informasi mengenai suatu atau aspek yang ingin diteliti. Adapun posisi dalam penelitian ini di MAN Rejang Lebong. Adapun yang menjadi subyek penelitian adalah sebagai berikut: Waka kurikulum di MAN Rejang Lebong, Guru mata pelajaran PAI (Fiqih dan Akidah Akhlak) di MAN Rejang Lebong. Teknik pengumpulan data yang dipergunakan dalam penelitian ini adalah wawancara, observasi langsung, dan dokumentasi.

\footnotetext{
${ }^{1}$ Baso Intang Sappaile. Kompetensi Mengajar Minimal Bagi Guru Baru (Jurnal Pendidikan dan Kebudayaan, Vol. 12, No. 2)(Jakarta: Balitbang Depdiknas). 2007, h.69

${ }^{2}$ Dewi Salma Prawiradilga, Mozik Teknologi Pendidikan (Jakarta:Kencana, 2007), 4.

${ }^{3}$ Abdul Manab, Penelitian Pendidikan Pendektan Kualitatif (Yogyakarta: Kalimedia, 2015), h $54-55$
} 


\section{Hasil dan Pembahasan}

Penelitian Ini Memaparkantentang Inovasi Pembelajaran Berbasis Web Dalam Implemntasi Kurikulum 2013 Di Man Rejang Lebong. Tujuh responden memberikan pendapat mereka dan dijelaskan dengan pembahasan berikut.

\section{Proses Pembelajaran yang Dilakukan Dimasa Pandemi Covid19 Di MAN Rejang Lebong.}

Seperti kita ketahui ketersediaan media teknologi seperti perangkat komputer juga menjadi faktor pendukung dalam keberhasilan kegiatan pembelajaran di mana hendaknya tersedia jumlah komputer yang harus memadai dan juga jaringan internet sebagai akses untuk memperoleh informasi juga harus baik, sehingga kegiatan belajar mengajar dapat berjalan dengan baik dan tujuan inovasi pembelajaran akan tercapai. Selain itu letak perangkat yang tepat dan strategis juga akan mendukung kelancaran proses pembelajaran anatar guru dan siswa karena memudahkan dalam mengakses internet. $^{4}$

Berkenaan dengan teori diatas dapat peneliti simpulkan bahwa di proses pembelajaran di MAN RL jika dilihat dari ketersediaan sarana teknologi dan informasi yang tersedia hal ini dapat dilihat dari adanya akses internet.ruang komputer dan letak yang tepat di mana juga tersedia 2 ruangan yang khusus untuk melakukan pembelajaran berbasis Web dengan teknologi dan informasi, selama pembelajara daring juga tersdianya android dari masing-masing siswa dan kuota ,sehingga pencapaian inovasi dalam teknologi dan informasi di MAN Rejang Lebong dapat terwujud.

Secara garis besar MAN Rejang Lebong sudah memiliki fasilitas teknologi yang memadai, hal ini terbukti dengan adanya fasilitas wi-fi dan kuota untuk melancarkan proses pembelajaran berbasis web, dengan kapasistas kuota 60 GB selama 3 bulan awal pandemi melanda Indonesia. Selain itu siswa dan guru di MAN Rejang Lebong memiliki android masing-masing, sehingga kuota dan android yang siswa miliki tersebut dapat dimanfaatkan siswa login ke websit MAN RL, mengirim tugas baik itu tulisan, hafalan atau video praktek melalui WA grub, Telegram atau E-mail, guru dan siswa melakukan pembelajaan kelas secara daring baik itu guru menjelaskan, siswa bertanya, memberi tugas dan kuis melalui Google class room, Google form, dan Zoom dalam melaksanakan proses pembelajaran jarak jauh selama pandemi Covid-19.

MAN Rejang Lebong mengadopsi ujian sekolah yang berbasiskan Android. Sejak kepemimpinan Bapak H. Saidina Ali, banyak peningkatan dalam fasilitas pendukung pembelajaran yang diberikan untuk Madrasah yang telah terbentuk sejak tahun 1990 ini. Diantaranya yakni pemenuhan fasilitas Laptop dan Komputer untuk proses belajar mengajar yang kian hari kian tercukupi. Hal ini tidak terlepas dari dukungan penuh para orang tua siswa. Sejalan dengan hal tersebut Tahun ajaran ini MAN Rejang Lebong sudah melaksanakan Ujian Madrasah, Ujian Semester dan Mid Semester menggunakan Android. Dengan kata lain, harapan besar untuk bisa menjadikan MAN RL setara dengan sekolah-sekolah maju yang ada di Pulau jawa. Sesuai dengan perkembangan IT dan generasi Milenial.

Dari hasil pengamatan yang dilakukan peneliti, inovasi pemebelajaran berbasis web yang dilakukan dilihat dari guru mengajar. Dimana guru memberikan materi pembelajaran secara daring disesuaikan dengan materi pembelajaran yang akan diberikan. berkenaan dengan inovasi teknologi harus diapresiasi karena pihak madrasah tidak hanya menginginkan madrasahnya yang ketinggalan dengan perkembangan

${ }^{4}$ Syaiful Bahri Djamarah, Aswan Zain, Strategi Belajar Mengajar. (Jakarta : PT. Rineka Cipta,1997), Hal . 136. 
zaman, namun di harapkan menjadi contoh untuk sekolah yang lain, serta madrasah yang memiliki ciri khas lain dalam hal ini adanya inovasi ketersediaan teknologi informasi dan jaringan internet dengan ujian berbasis web menggunakan android yang belum dimiliki oleh sekolah lainnya.

\section{Inovasi Pembelajaran Berbasis Web dalam Implementasi Kurikulum 2013 di MAN Rejang Lebong}

Perkembangan selanjutnya dipengaruhi oleh teori belajar konstruktivisme. Komputer dimanfaatkan untuk membantu siswa menemukan dan merumuskan pengetahuannya melalui interaksi dan eksplorasi sumber-sumber belajar berbasis teknologi informasi. Selain itu, pemanfaatan teknologi dalam pembelajaran juga mendukung teori socio-constructivism, yakni siswa memperoleh pengalaman belajar secara bersama-sama dengan siswa lain atau melalui interaksi dengan para pakar dengan media komunikasi berbasis web. Perkembangan terkini adalah pemanfaatan teknologi secara terpadu di dalam pembelajaran yang memadukan berbagai keterampilan dan fungsi teknologi dalam proses belajar mengajar. Adapun pembelajaran melalui web internet yang memanfaatkan teknologi informasi ini antara lain bimbingan belajar online seperti Quipper, Ruangguru, dan Zenius serta platform Edmodo dan Google Classroom. ${ }^{5}$

Pembelajaran biasanya berlangsung dengan metode face to face atau sistem langsung. Namun dengan berkembangnya teknologi sekarang ini, belajar tidak selalu harus berhadapan langsung antara guru dan murid. Belajar online bisa dibilang lebih efisien secara waktu dan tempat, karena dapat dilakukan di waktu senggang dan di manapun, selama koneksi internet lancar. Di Indonesia, banyak sekali website yang menyediakan atau menawarkan jasa belajar online. Ada beberapa di antaranya yakni Ruangguru, Quipper, dan Zenius. Semua website tersebut memiliki keunggulan pada sektor produk dan keefisienan cara belajarnya. Ruangguru, Quipper, dan Zenius memiliki metode belajar, cara belajar, dan sistem belajar yang berbeda.

Dari hasil wawancara tentang inovasi pembelajaran berbasis web ,media pembelajaran di MAN Rejrang Lebong ternyata Guru mata Pelajaran Fikih memiliki inovasi penggunaan media web yaitu menggunakan WA dan Google Form, Class room, dan Akidah Akhlak memiliki kreatifitas dan inovasi penggunaan media berbasis web yaitu menggunakan Telegram dan Youtube pembelajaran dengan sangat menarik dan sangat memahami kondisi siswa, pasalnya tidak semua siswa mampu dalam segi kuota, sinyal bahkan handpone (HP) yang mereka miliki itu berbeda-beda tipenya,sehingga guru memiliki inovasi dalam penggunaan media sesuai dengan kemampuan siswa.

Inovasi dalam metode pembelajaran yang digunakan guru di MAN Rejang Lebong bermacam-macam, sesuai dengan kebutuhan pembelajarannya masing-masing, di sini guru dituntut untuk memiliki inovasi dalam mengajar di masa pandemi, dapat kita analisa bahwa pembelajaran pada masa daring ini banyak sekali kendalanya terutama siswa, jadi apapun kendala yang ada pada siswa, guru dituntut untuk profesional dalam penggunaan metode pengajaran agar apa yang disampaikan guru dapat dipahami dengan mudah oleh siswa.

Proses pembelajaran selama musim Pandemi Covid 19 adalah menggunakan metode dalam jaringan yang disebut dengan sebutan "DARING". Metode ini mengedepankan metode belajar yang berlansung secara jarak jauh menggunakan media jaringan Medsos. Jaringan Medsos berupa Internet yang menyambungkan koneksi

5 Yuliana, "Inovasi Pembelajaran Melalui Teknologi Informasi: Pengembangan Model Pembelajaran Melalui Internet” Jurnal Islamic Education Menajemen 4 (1) (2019) 119-132 
melalui Hp, Laptop, In Fokos, dan bisa juga bentuk media layar lebar. layanan Medsos menggunakan jaringan ini dapat diguankan melalui jenis media yang berbasis web yaitu whatsapp, blog, zoom, class room, e-mail, youtube, telegram dan banyak lagi yang lain.

Sistem Daring ini juga memiliki prinsip, sehingga pembelajaran mampu memberikan manfaat baik bagi guru maupun peserta didik. Prinsip tersebut adalah: pertama, daring sebagai alat bantu proses pembelajaran sehingga dapat menyelesaikan masalah, menghasilkan kreativitas, membuat proses pembelajaran lebih mudah, terarah dan bermakna; kedua, Daring sebagai sebuah alternatif dalam sistem pendidikan memiliki prinsip high-tech-high-touch yaitu prosesnya lebih banyak bergantung kepada teknologi canggih dan lebih penting adalah aspek high touch yaitu guru atau peserta didik; ketiga, sesuaikan daring dengan kesiapan guru, peserta didik, fasilitas dan kultur sistem pembelajaran. ${ }^{6}$

Dari hasil wawancara peneliti dapat simpulkan bahwa guru PAI pada mata pelajran Fikih dan Akidah Akhlak memiliki inovasi dan ide dalam penggunaan media dan metode pengajaran yang sesuai dengan kebutuhan siswa. Dari hal ini dapat membuktikan bahwa guru di MAN Rejang Lebong sangat inovasi dalam penyampaian Materi pembelajaran dan sangat memahami kondisi siswa apalagi di masa pandemi ini.

\section{Cara Membentuk Karakter Kurikulum 2013 Dimasa Pandemi Covid-19}

Implementasi kurikulum 2013 merupakan aktualisasi kurikulum dalam pembelajaran dan pembentukan kompetensi serta karakter peserta didik. ${ }^{7}$ Dari hasil penelitian tersebut dapat disimpulkan bahwa pembentukan karakter di kurikulum 2013 selama pandemi ini tentu ada kesulitan dan hambatannya, tetapi sebagai guru dituntut untuk menjadi pendidik yang profesional menghadapi tantangan pendidikan, salah satunya pembentukan karater siswa. Apalagi dimasa pandemi ini siswa dan guru melakuakn pembelajaran secara daring sehingga untuk membentuk dan menilai karakter siswa itu sangat sulit karna siswa tidak berada di dekat guru.

Selain masalah sinyal dan kuota selama proses pembelajaran daring ini, tentu pembentukan karakter menjadi problem di masa pandemi ini, terkhusus guru Fikih dan Akidah Akhlak tentunya memiliki kesiapan dalam mengatasi problem yang mereka dapatkan di dalam proses pembelajaran yang dilakukan secara daring ini, adapun cara yang dilakukan ibu iim sebagai guru fikih mengevaluasi karakter siswa dengan cara melihat chat pribadi siswa, keaktifan saat pertemuan, mengumpulkan tugas tepat waktu dan kehadiran setiap melakukan magrib mengaji, sedangkan untuk bapak rio marco selaku guru Akidah Akhlak yang mengevaluasi karakter siswa dengan cara melihat kejujuran siswa dari hafalan, sebelum melaksanakan pembelajaran harus sholat duha, siswa menjadi kreativ dalam membuat video praktek hafalan sehingga dari hal iru bisa melihat karakter kejujuran pada siswa.

Secara keseluruhan dari pemaparan di atas dapat di sumpulkan bahwa karakter kurikulum 2013 di MAN Rejang Lebong sudah dapat dikatakan dapat di bentuk dengan cara yang kreatif dan inovatif dilakukan masing-masing guru dalam mengatasi problem pembentukan karakter siswa, sehingga karakter kurikulum 2013 bisa dikatakan tercapai atau terbentuk dengan penilaian yang guru lakukan.

\footnotetext{
${ }^{6}$ Munir, Pembelajaran Jarak Jauh Berbasis Teknologi Informasi dan Komunikasi (Bandung: Alfabeta, 2009), h. 174-176.

${ }^{7}$ Imas Kurniasih dan Berlin Sani, Sukses Mengimplementasikan Kurikulum 2013 Memahami Berbagai Aspek dalam Kurikulum 2013, (Jakarta: Kata Pena), 2014,h. 5-7
} 


\section{Kesimpulan}

Berdasarkan paparan dalam hasil penelitian tersebut mengenai pembelajaran berbasis web dan implementasi dalam kurikulum 2013, dapat ditarik kesimpulan sebagai berikut:

1. Proses pembelajaran yang dilakaukan di masa Pandemi Covid-19, membutuhkan proses yang bermacam-macam proses pembelajaran di MAN RL jika dilihat dari ketersediaan sarana teknologi dan informasi yang tersedia hal ini dapat dilihat dari adanya akses internet, ruang komputer dan letak yang tepat di mana juga tersedia 2 ruangan yang khusus untuk melakukan pembelajaran berbasis Web dengan teknologi dan informasi, selama pembelajara daring juga tersedianya android dari masing-masing siswa dan kuota ,sehingga pencapaian inovasi dalam teknologi dan informasi di MAN Rejang Lebong dapat terwujud.

2. Inovasi guru dalam mengimplementasi kurikulum 2013 di man rejang lebong, yaitu inovasi pembelajaran berbasisi web dalam bentuk media pembelajaran, inovasi pembelajaran berbasisi web dalam bentuk metode pembelajaran.

3. Cara Membentuk karakter kurikulum 2013 di MAN Rejang Lebong sudah dapat dikatakan dapat dibentuk dengan cara yang kreatif dan inovatif dilakukan masingmasing guru dalam mengatasi problem pembentukan karakter siswa, sehingga karakter kurikulum 2013 bisa dikatakan tercapai atau terbentuk dengan penilaian yang guru lakukan.

\section{Daftar Pustaka}

Bahri Djamarah. Syaiful, Aswan Zain, Strategi Belajar Mengajar. Jakarta: Rineka Cipta. 1997

Intang Sappaile. Baso. Kompetensi Mengajar Minimal Bagi Guru Baru (Jurnal Pendidikan dan Kebudayaan, Vol. 12, No. 2). Balitbang Depdiknas. 2007

Kurniasih. Imas, dan Berlin Sani. Sukses Mengimplementasikan Kurikulum 2013; Memahami Berbagai Aspek dalam Kurikulum 2013. Jakarta: Kata Pena. 2014

Manab, Abdul. Penelitian Pendidikan Pendektan Kualitatif. Kalimedia, 2015

Munir. Pembelajaran Jarak Jauh Berbasis Teknologi Informasi dan Komunikasi. Bandung: Alfabeta. 2009

Salma Prawiradilga. Dewi. Mozik Teknologi Pendidikan. Jakarta: Kencana. 2007

Yuliana. Inovasi Pembelajaran Melalui Teknologi Informasi: Pengembangan Model Pembelajaran Melalui Internet. Jurnal Islamic Education Menajemen 4. 2019 